\title{
Erratum to: Effects of feeding different dietary protein and energy levels of the performance of 12-15-month-old buffalo calves
}

Muhammad Aasif Shahzad • Nasir A. Tauqir •

Fayyaz Ahmad • Mahr U. Nisa - Muhammad Sarwar •

Murtaza A. Tipu

Published online: 14 February 2011

(C) Springer Science+Business Media B.V. 2011

Erratum to: Trop Anim Health Prod

DOI 10.1007/s11250-010-9753

Name of co-author needs to be read as Murtaza A. Tipu instead of Muhammad A. Tipu.

The online version of the original article can be found at http://dx.doi. org/10.1007/s11250-010-9753-5.

M. A. Shahzad $(\bowtie) \cdot$ N. A. Tauqir $\cdot$ M. U. Nisa $\cdot$ M. Sarwar Institute of Animal Nutrition and Feed Technology,

University of Agriculture,

Faisalabad, Pakistan

e-mail: draasifshah@uaf.edu.pk

F. Ahmad • M. A. Tipu

Buffalo Research Institute,

Pattoki District Kasur, Pakistan

M. A. Tipu

e-mail: aasifshah9@hotmail.com 